\title{
Tuberous Root Initiation and Shoot Regeneration in Telfairia occidentalis Hook. F.
}

\author{
Ayobola Moninuola Sakpere ${ }^{1}$ And Idowu Arinola Obisesan ${ }^{2}$ \\ Department of Botany, Obafemi Awolowo Univesity, Ile-Ife, Nigeria. ${ }^{1 \& 2}$
}

\begin{abstract}
The study assessed tuberous root development, cotyledon degeneration and shoot regeneration in Telfairia occidentalis. This was with a view to establishing the tuberous root function in shoot regeneration, relationship between cotyledon degeneration and tuberous root initiation and the possibility of shoot regeneration if cotyledons are lost. Seeds from matured fruits of T. occidentalis were utilized in this study. Seedlings were uprooted at weekly intervals on a random basis to observed tuberization. Plants were also uprooted at weekly intervals, a week after tuberization and the primary shoots excised at the base, replanted and watered regularly to determine possibility of shoot regeneration. As control, primary shoots of 3 weeks old plants were excised, replanted and watered regularly for the possibility of shoot regeneration. To observe correlation between root development and cotyledon degeneration, six randomly selected plants were uprooted on a weekly basis, and weights of cotyledon and root measured and their means compared. Cotyledons and roots were excised from plants, and where observed for possibility of shoot regeneration. The study concluded that root tuberization in T. occidentalis was initiated at the onset of cotyledon degeneration and the food and energy reserve needed for shoot regeneration where translocated to the root at this time.
\end{abstract}

Keywords: Cotyledon degeneration, Nexus, Telfairia occidentalis, Shoot regeneration, Tuberous root.

\section{Introduction}

Telfairia occidentalis Hook. F., is a tropical plant, belonging to the family Cucurbitaceae. This family consists of approximately 120 genera and about 850 species, which are distributed all over the warm parts of the world ([1], [2], [3]). T. occidentalis is a dicotyledonous plant which is partially drought and shade-tolerant [4]. Among the indigenous vegetables, T. occidentalis is widely eaten in Nigeria and cultivated for its edible succulent shoot and leaves as a backyard crop. However, it is predominantly used by the Igbo tribe, who continue to cultivate the gourd for food sources and traditional medicines ([2], [5]). T. occidentalis possess relatively large seeds. The large seeds sizes generally have a positive influence on the rate of seedling emergence, growth and development of $T$. occidentalis plant [6]. The plant is known to have a great ethnomedicinal value. There are as many beneficial as there are harmful chemical substances in different parts of the plant [7]. The leaves are rich in iron, as a result of which fresh leaf concoction is used as a health tonic for the treatment of anaemia ([5],[8]). The leaves are also rich in protein $(29 \%)$, fat (18\%), minerals and vitamins (20\%) [9], the plant has also been reported to contain considerable amount of anti-nutrients [10]. The roots are used as rodenticide and ordeal poison [11]. The roots have high alkaloid content and their extracts are therefore used for controlling pest and rodents ([12],[13]).

Cotyledons are seed leaves that are present in the embryo even before seed germination as colourless leaves. They are thin and membranous in endospermic seeds (e.g. pea). During seed germination, cotyledons may remain in the seed (hypogeal) or emerge above the ground and become first photosynthetic structures by becoming green (epigeal) [14]. Cotyledons are critical sources of energy and nutrients, and thus cotyledon damage or loss can have detrimental effects on plant growth both at the seedling stage and carrying on to maturity ([15],[16],[17],[18]). Ipomoea hederacea, for example, can completely compensate for damage to mature leaves but not cotyledons [19]. In several large-seeded species, a large amount of seed biomass remains in cotyledons even after development of functional shoot [20]. Several ecologists have argued that the biomass remaining in cotyledons provides reserves that can be used for growth and survival of seedlings in the presence of stress factors such as low light, frequent shoot destruction, and strong competition ([21],[22],[23],[24],[25],[26],[27],[28],[29],[30],[31]).

It is also known that the cotyledons of some other species may remain attached to the stem for a long period after seed reserves cease to be mobilized, but are kept as an insurance that would allow recovery from accidental shoot loss [31]. Persistence of cotyledons may ultimately depend on the development of sufficient root mass for reserve reallocation [32]. Shade-tolerant species (such as T. occidentalis) tend to have large seeds, storage cotyledons and inherently slow relative growth rate via low specific leaf area and leaf area ratio ([26],[33],[34],[35]). The members of family Cucurbitaceae are annual or perennial tendrillar, climbers and some perennial plant taxa, for example Talinum triangulare, bear tuberous root [36]. 
Plant root tubers share one or two biological roles. The first is to store carbon and usually also nitrogen in a form that can be mobilized when required. In perennials such as cassava the storage may be long term, whereas in biennials and annuals it is from one season to the next. The second property which is shared by most, but not all, tubers is that they act as propagules, in that they are able to sprout and give rise to new plants. In this case they need to contain a sufficiently wide range of nutrients to support the requirements of the plant until it is capable of independent growth [37]. Telfairia occidentalis is an herbaceous facultative perennial, whose aerial shoot dies annually but is replaced after an interval of time by new shoots from underground rootstock. Though mainly propagated from seed every year, a reasonable percentage of old plants regenerate from rootstocks left in the ground after total or partial shoot senescence at the end of the previous season [38].

Tuberous root stock in $T$. occidentalis functions in shoot regeneration. The relationship between the initiation of tuberous root and cotyledon degeneration has not been established. There is therefore the need to investigate the time of initiation of tuberous root and the age at which it can function in shoot regeneration.

This study investigated the time of initiation of tuberous root in T. occidentalis, cotyledon degeneration after the development of tuberous root in the plant, the age of tuberous root that may function in shoot regeneration and also, if cotyledons are lost, will new shoots sprout?.

\subsection{Experiment 1}

\section{Materials and Methods}

Seeds from matured fruits of Telfairia occidentalis were utilized in this study. In May 2015, 600 seeds of Telfairia occidentalis were sown into 120 experimental buckets (22cm (depth) $20 \mathrm{~cm}$ (diameter)) in an open field at Obafemi Awolowo University Ile Ife, Osun State, Nigeria (Latitude $7^{\circ} 31^{\prime} \mathrm{N}$ and Longitude $4^{\circ} 31^{\prime} \mathrm{E}$ ). With Mean Annual Rainfall of $1474.5 \mathrm{~mm}$, Mean annual temperature range of $20.3^{\circ} \mathrm{C}$ to $28.6^{\circ} \mathrm{C}$ and an average daily light intensity of 100200 Lux meter. Five seeds each were sown $(2 \mathrm{~cm}$ depth) into the experimental bucket filled with top soil. The bowls were perforated at the base to allow good drainage and watered on a daily basis. The soil around the potted plants was cleared to remove debris. Two weeks after planting, they were thinned to 3 plants per buckets. Three hundred and sixty (360) plant stands were established from the seeds sown.

On a weekly basis, beginning from the end of the fourth week after sowing, six (6) T. occidentalis plants each were uprooted from the potted plants, washed under a running water to remove the soil attached to the root and dried with blotting paper and the roots were noted for tuberization.

Five weeks after germination, six (6) randomly selected plants from the pots were carefully uprooted weekly, and the following weights (cotyledons and roots) were measured:

\section{Fresh Weight}

The 6 plants carefully uprooted were washed under a running water, to remove the soil attached to the cotyledons and the roots. The cotyledon and the root were dried with blotting paper, the cotyledons were carefully cut-off from the roots and they were separately weighed on a Mettler Toledo (PB 153) electronic balance to obtain their individual Fresh Weights.

\section{Dry Weight}

Each cotyledon and tuberous root were packaged in separate envelope and dried in a Gallenkamp (model $1 \mathrm{H}-$ 150) oven at $80^{\circ} \mathrm{C}$ to a constant dry weight. Their Dry Weights were obtained on a Mettler Toledo (PB 153) electronic balance.

\subsection{Experiment 2}

650 seeds of Telfairia occidentalis were sown into 130 experimental buckets $(22 \mathrm{~cm}$ (depth) $20 \mathrm{~cm}$ (diameter)) in an open field at the rate of 5 seeds per buckets and watered daily with $500 \mathrm{ml}$ per buckets, 2 weeks (14 days) after sowing, the seedlings were thinned to 3 plants per buckets, three hundred and ninety (390) plant stands were established from the seeds sown. At week 3, a total of 36 plants were carefully uprooted and cleared of debris. This plants were separated into six groups (i.e. 6 replicates per group) viz:

A pair of cotyledon only (i.e. excised root)

1 cotyledon with root (i.e. excised cotyledon)

2 Coty Only

1 cotyledon without root (i.e. excised root and 1cotyledon) - $\quad$ Coty Only

Root only (i.e. cotyledon pair excised)

R Only

No cotyledon no root (i.e. both root and cotyledon excised) - $\quad$ No Coty-No R

A pair of cotyledon with intact root - Control

The primary shoot of the 6 plants from each group were excised from the base, replanted and watered (300 ml) regularly to determine the possibility of shoot regeneration, 1 week after from the excised plants. This procedure was repeated on a weekly basis from week 3 to week 12 . 


\section{Statistical Analysis}

Means of weekly data obtained from fresh and dry weights of cotyledon and root from Experiment 1 were compared using Pearson Correlation. Differences between the mean levels of fresh and dry weights of cotyledons and roots were taken to be statistically significant at $\mathrm{P}<0.05$. Data obtained from the number of regenerated shoots from Experiment 2, from plants with different excised plants and control were subjected to One-way ANOVA and their means separated by LSD, using system analysis software (SAS) version 9.1 . (P < $0.05)$

\subsection{Experiment 1}

\section{Results}

Four weeks to seven weeks root were observed to be non-tuberous, but beginning from week eight the roots were noted to become tuberous (Fig. 1a \& b).

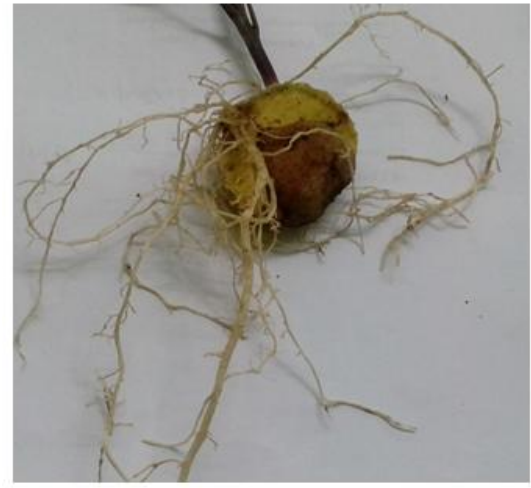

Cotyledon

Non-tuberous root

Figure 1a: Root of T. occidentalis before tuberization (4 weeks old) (X1.6).

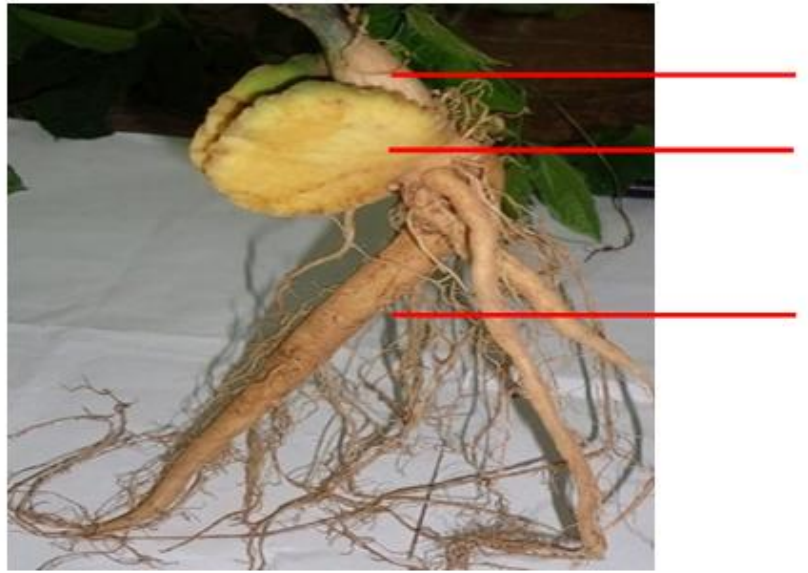

Swollen nexus

Cotyledon

Tuberous root

Figure 1b: Root of T. occidentalis after tuberization (9 weeks old) (X 1.6).

\subsection{Determination of Relationship between Cotyledon Degeneration and Root Development.}

There was an increase in the mean root fresh weights with increase in the number of weeks, with an exception at week 13; where there was a decrease in the mean fresh weight. There was also a fluctuation in cotyledon mean fresh weights from week 5 to week 10 and decrease in mean fresh weights from week 10 to 14 (Fig. 2). The root mean dry weight increases with time (Fig. 2), with an exception at week 13 where there was a decrease in mean dry weights of the root. Mean dry weights of the cotyledons fluctuated with time. There was however, an overlap between the cotyledon and the root mean dry weights at week 8 , which means there was no significant difference between cotyledon and root mean dry weight at week 8 .

In Fig 3, cotyledon degeneration and root development were compared using Pearson Correlation test. A best fit straight regression line was plotted with coefficient of determination, $\mathrm{R}^{2}=0.7435$ and 0.8698 for linear correlation between mean cotyledon degenerated and mean root development. There was a strong negative significant correlation between the mean fresh weights of cotyledon and the mean fresh weight of the roots in T. occidentalis $(\mathrm{r}=-0.932, \mathrm{n}=12, \mathrm{p}<0.05)$. A strong negative significant correlation between the mean dry weight of cotyledon and the mean dry weight of the root in T. occidentalis $(\mathrm{r}=-0.862, \mathrm{n}=12, \mathrm{p}<0.05)$ was observed. 


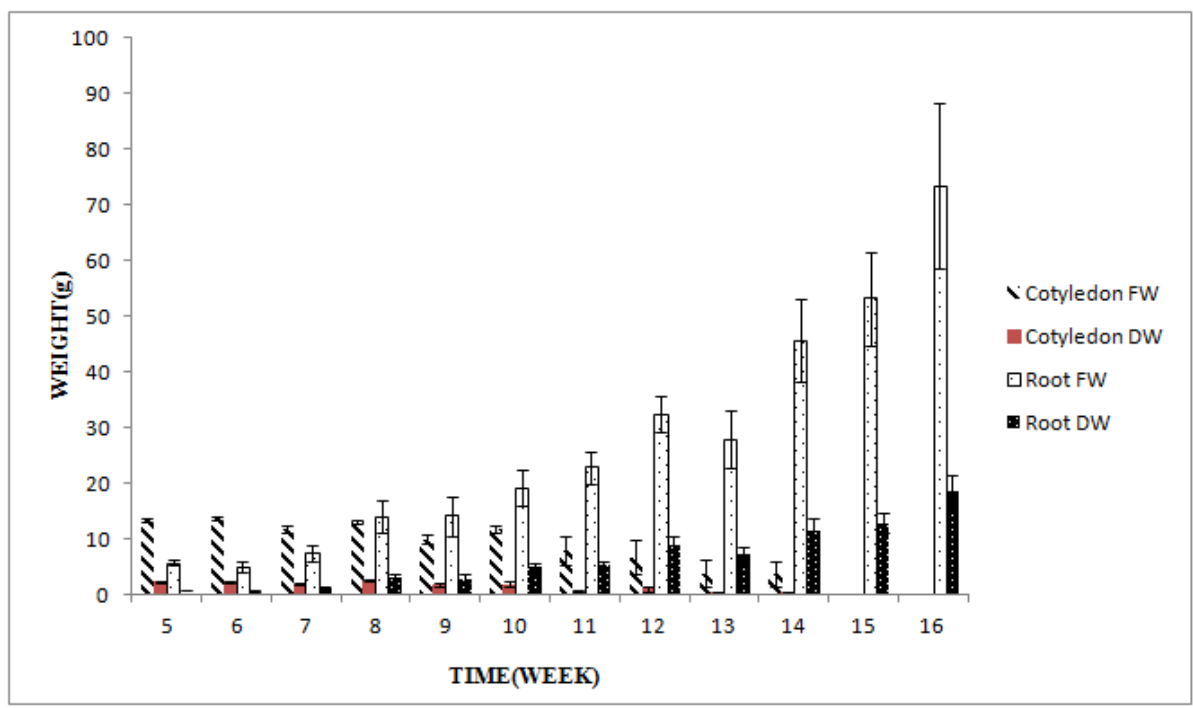

Figure 2: Relationship between Cotyledon and Root weights of T. occidentalis with time.

Bars represent means of six replicates $\pm \mathrm{SE}$
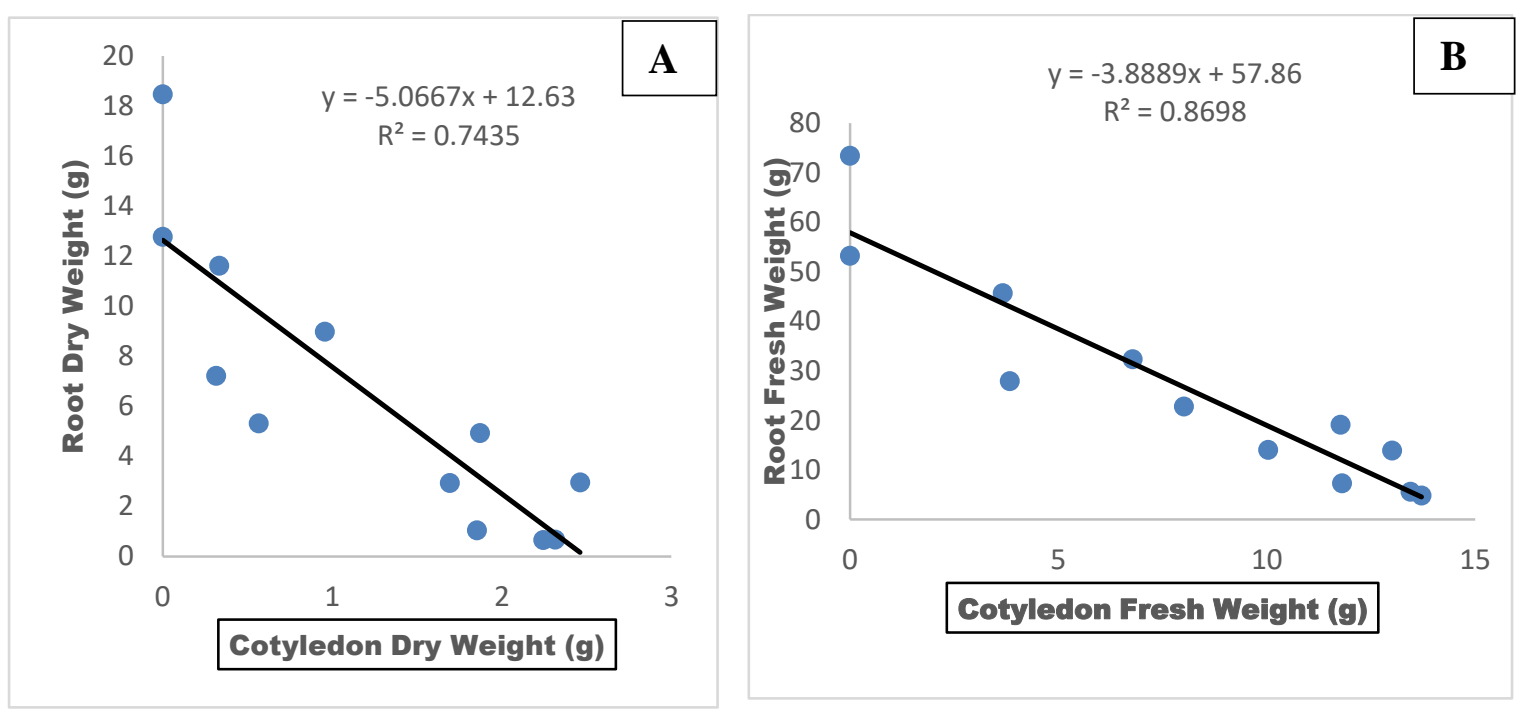

Figure 3: Correlation between the Cotyledon Weight (g) and Root Weight (g)

\section{Experiment 2:}

Table 1: Shoot regeneration from different excised plant organs in $T$. occidentalis from week 3 (i.e. before tuberization) to week 12 (i.e. after tuberization)

\begin{tabular}{|c|c|c|c|c|c|c|c|c|c|c|}
\hline & WK 3 & WK 4 & WK 5 & WK 6 & WK 7 & WK 8 & WK 9 & WK 10 & WK 11 & WK12 \\
\hline Control & $1.83 \pm 0.16^{\mathrm{a}}$ & $1.17 \pm 0.17^{b}$ & $1.00 \pm 0.00^{b}$ & $1.17 \pm 0.17 \mathrm{sb}$ & $1.17 \pm 0.17^{\mathrm{sb}}$ & $1.50 \pm 0.22^{\circ}$ & $1.33 \pm 0.21^{\mathrm{abc}}$ & $1.33 \pm 0.21 \mathrm{sb}$ & $1.50 \pm 0.22^{\mathrm{ab}}$ & $1.67 \pm 0.21^{\mathrm{b}}$ \\
\hline 2Coty Only & $1.00 \pm 0.37 \mathrm{bc}$ & $1.33 \pm 0.21^{b}$ & $1.33 \pm 0.00^{\mathrm{sb}}$ & $1.33 \pm 0.49^{\mathrm{a}}$ & $1.83 \pm 0.31^{\mathrm{a}}$ & $2.17 \pm 0.31^{\mathrm{bc}}$ & $1.57 \pm 0.22^{\mathrm{abc}}$ & $1.33 \pm 0.21^{\mathrm{ab}}$ & $0.67 \pm 0.21^{c}$ & $0.33 \pm 0.21^{\circ}$ \\
\hline 1 Coty Only & $1.00 \pm 0.00^{\mathrm{sb}}$ & $1.33 \pm 0.33^{b}$ & $2.17 \pm 0.40^{\mathrm{s}}$ & $0.83 \pm 0.17 \mathrm{abc}$ & $2.00 \pm 0.52^{\mathrm{a}}$ & $3.00 \pm 0.37 \mathrm{~s}$ & $1.00 \pm 0.26 \mathrm{bc}$ & $0.83 \pm 0.17 \mathrm{bc}$ & $0.67 \pm 0.21^{\circ}$ & $0.33 \pm 0.21$ \\
\hline 1 Coty $+R$ & $1.00 \pm 0.00^{\mathrm{bc}}$ & $2.00 \pm 0.26^{a}$ & $1.50 \pm 0.50^{\mathrm{ab}}$ & $0.33 \pm 0.21^{\mathrm{cd}}$ & $2.00 \pm 0.52^{\mathrm{a}}$ & $2.33 \pm 0.21 \mathrm{ab}$ & $1.83 \pm 0.31^{\mathrm{a}}$ & $1.67 \pm 0.21^{\mathrm{a}}$ & $1.83 \pm 0.31^{\mathrm{a}}$ & $2.50 \pm 0.22$ \\
\hline R Only & $0.67 \pm 0.21^{\circ}$ & $0.00 \pm 0.00^{\circ}$ & $1.00 \pm 0.00^{\mathrm{b}}$ & $0.50 \pm 0.22^{\mathrm{bcd}}$ & $0.33 \pm 0.21 \mathrm{bc}$ & $2.17 \pm 0.17 \mathrm{bc}$ & $1.67 \pm 0.33^{\mathrm{ab}}$ & $1.83 \pm 0.31^{\mathrm{a}}$ & $1.83 \pm 0.31^{\mathrm{a}}$ & $2.50 \pm 0.22=$ \\
\hline \multicolumn{11}{|l|}{ No Coty - } \\
\hline No Root & $0.00 \pm 0.00^{\mathrm{d}}$ & $0.00 \pm 0.00^{\circ}$ & $0.00 \pm 0.00^{\circ}$ & $0.00 \pm 0.00^{d}$ & $0.00 \pm 0.00^{\circ}$ & $0.33 \pm 0.21^{d}$ & $0.83 \pm 0.17 \mathrm{c}$ & $0.67 \pm 0.21^{\circ}$ & $1.00 \pm 0.26^{\mathrm{bc}}$ & $1.67 \pm 0.21^{b}$ \\
\hline
\end{tabular}

*Values in each column followed by the same letter are not significantly different at $\mathrm{P}<0.05$. Each value represented the mean $\pm \mathrm{SE}, \mathrm{n}=6$ determinations. 


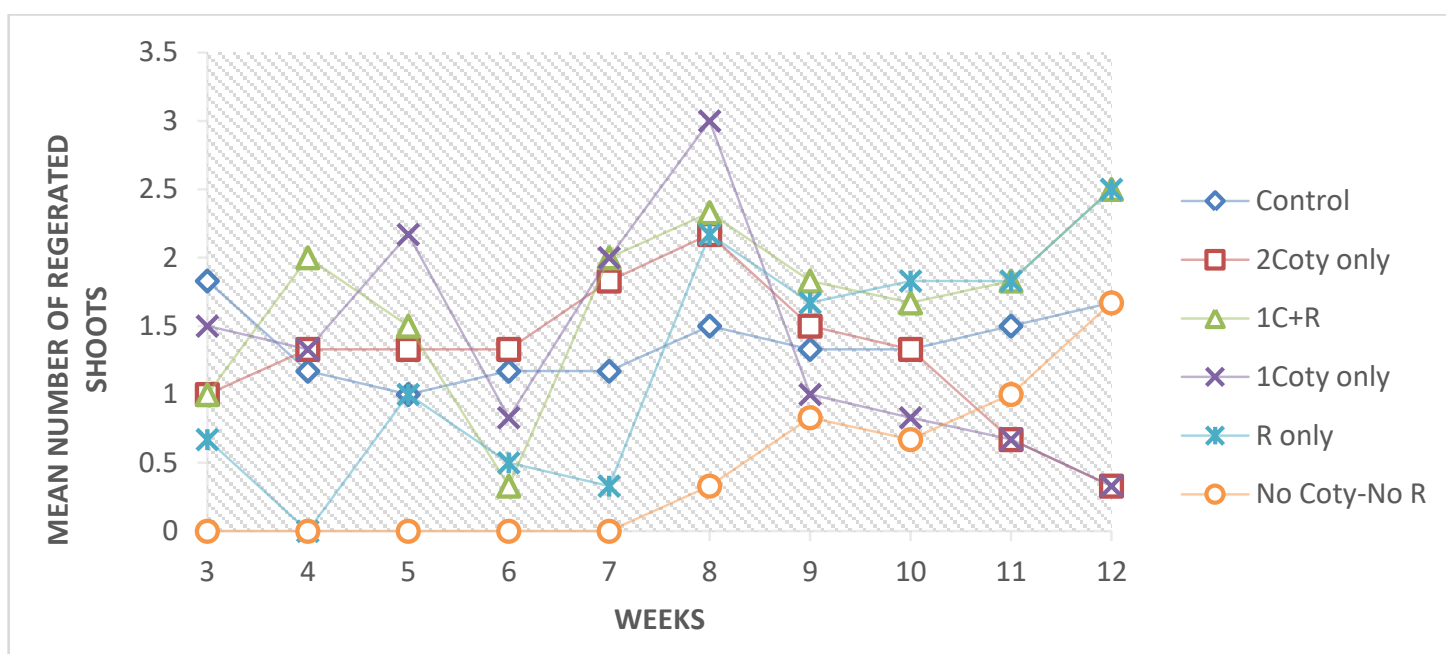

Figure 4: Mean Shoot Regenerated from week 3 to week 12 in T. occidentalis

At week 3: Mean regenerated shoots from Control group were significantly higher than that of all other groups but not significantly different from group with 1Coty only. Mean number of regenerated shoots from 2Coty only and 1 Coty $+\mathrm{R}$ were not significantly different from each other, but were not significantly higher than shoots regenerated from plants with $\mathrm{R}$ only, with the No Coty-No $\mathrm{R}$ group having no regenerated shoot (Table 1).

At week 4: Plants from 1 Coty $+\mathrm{R}$ group had the highest number of regenerated shoots, followed by control, 2 Coty only and 1Coty only groups, which were not significantly different from one another, with the R only and No Coty-No R group having no regenerated shoot (Table 1).

At week 5: Plants with $1 \mathrm{C}$ only had the highest number of regenerated shoots, but not significantly higher than that of 2 Coty only and $1 \mathrm{C}+\mathrm{R}$ groups. Shoot regeneration from Control and R only groups were not significantly higher than each other but lower than the former group, with no shoot regeneration from No Coty-No R group (Table 1).

At week 6: plants with 2Coty only had the highest number of regenerated shoots, but not significantly higher than control and 1Coty only groups. Plants with $\mathrm{R}$ only and 1 Coty+R had the lowest mean shoot regeneration, with no shoot regeneration from No Coty-No R group (Table 1).

At week 7: 1Coty+R, 1Coty only and 2 Coty only had the highest number of regenerated shoots, but not significantly higher than Control, with R only group having the lowest mean shoot regeneration, with no shoot regeneration from No Coty-No R group (Table 1).

At week 8: 1Coty only had the highest mean number of regenerated shoots, but not significantly higher than $1 \mathrm{C}+\mathrm{R}$ group. Mean shoot regenerated from 2 Coty only and $\mathrm{R}$ only groups were not significantly different from each other, but not significantly higher than the Control group, and the No Coty-No R having the lowest mean number of regenerated shoots (Table 1).

At week 9: 1C only group had the highest mean number of regenerated shoots, but these were not significantly higher than R only, 2 Coty only and the control groups respectively. While 1Coty only and No Coty-No R groups had the lowest but non-significantly different mean number of regenerated shoots (Table 1).

At week 10: $\mathrm{R}$ only and 1 Coty+ $\mathrm{R}$ had the highest mean number of regenerated shoots, but not significantly higher than the control and 2Coty only groups. 1Coty only and No Coty-No R groups had the lowest but nonsignificantly different mean number of regenerated shoots (Table 1).

At week 11: 1 Coty $+R$ and $R$ only had the highest mean number of regenerated shoots, but not significantly higher than the Control group. The mean number of shoot regenerated from No Coty-No R group at this week were not significantly higher than 2Coty only and 1 Coty only groups (Table 1).

At week 12: 1 Coty $+R$ and $R$ only groups had the significantly highest mean number of regenerated shoot, followed by the Control and No Coty-No R group. With the 2Coty only and 1Coty only groups having the significantly least mean number of regenerated shoots (Table 1).

The control experiment had it peak at week 3 (i.e. before tuberization), both 1Coty only and 2Coty only groups had their peak at week 8 (at tuberization) and 1Coty+R, R only and No Coty-No R groups had their peak at week 12 (i.e. after tuberization) when nexus is formed. Plants with cotyledons only (1Coty only and 2Coty only), had maximum shoot regeneration at week 8 (just when their roots becomes tuberous) and decline progressively till the end of the experiment (week 12). Plants with their roots intact (R only and 1 Coty+R), had relatively low mean shoot regeneration between week 3 and week 7(i.e. before tuberization), but this increase sharply between week 7 and week 8 (when tuberization becomes noticeable), but with their highest peak at 
week 12. Plants without roots and cotyledons had no shoot regenerated until week 8 when swollen nexus have developed, and shoot regeneration increased progressively till the end of the experiment (Fig 4).

\section{Discussion}

The essential roles of the root in plant are for anchorage, sites of synthesis of growth substances and as absorber and transporter of aqueous mineral solutions [39]. Telfairia occidentalis is known to germinate with epicotyl elongation and swelling in the area of the hypocotyls, the lateral growth occurring in the hypocotyl represents the early formation of a storage region that becomes the large, food-packed, perennial tuber ([40],[41]).

Tuberous root development depends on increase in number of cells and on starch accumulation in the cells ([42],[43]). The root of T. occidentalis [39] has been reported to become swollen and the rootstock becoming more prominent with increase in age. The age at which this begins to happen was however not elucidated. This study has shown clearly that tuberosity is observed as from eight weeks after planting. In this study, the tuberosity observed in the roots of eight weeks old T. occidentalis seedlings could be associated with increase in number of cells, massive starch accumulation and translocation of the cotyledonary reserve to the root at this point since cotyledons were noted to start degenerating from this week. Genetic component is however, also a major factor in determining whether a root becomes tuberous or not.

Cotyledons in seeds are known to store food reserves of plant amongst other functions. As plants advance in age, hypogeal cotyledons which have been functioning as a storage organ changes it role to that of backup energy for resprouting in case of shoot damage [44]. Removal (or damage) of T. occidentalis cotyledons has been reported to result in reduction in growth performance of seedlings but not necessarily the ultimate death of the seedling at its early stage of development depending on the degree of removal or damage [45]. This is because cotyledon reserves are important for resprouting during early seedling emergence and establishment, but do not directly contribute to seedling growth or biomass recovery from herbivores at the post-establishment stage [32].

In this study, cotyledon fresh and dry weights reduced gradually from week eight (8) onward, consequently, the root fresh and dry weights also increased, which agreed with an earlier report [20], that some of the cotyledon resources were translocated to roots and stored as reserves in an early period of seedling development. This could have been an adaptive value of coping in case of shoot damage. Hypogeous cotyledons of various species are often eaten by predators ([46],[29]). In addition, loss of cotyledon often occurs during seedling development. Thus, the risk of seedling losing carbohydrate reserves would be likely to increase cumulatively with time, if all the resources were contained in cotyledons. Therefore, translocation of some of these resources to roots in early periods of establishment may reduce the risk of the plant losing all their reserves through loss of their cotyledons.

As the tuberous roots become prominent (more matured) the percentage mass of remnant cotyledon also reduces. This implies that at about eight weeks, the tuberous root of Telfairia occidentalis became functional as the reserve organs and that the seedlings becomes independent of their cotyledon as a storage organ for growth, but these cotyledons might be very important for regeneration in case of shoot loss.

The swollen or tuberous roots in plant have been noted to be responsible for shoot regeneration, in case of damage to plants. The swollen roots of Chromolaena odorata [47] were reported to be important for its regeneration. Also, the tuberous root together with the swollen residual vine has been associated to be responsible for shoot regeneration in T. occidentalis [39]. In agreement with previous reports, T. occidentalis root upon tuberisation after eight weeks, functioned in shoot regeneration. However, in this study, non-tuberous roots of $T$. occidentalis with excised shoot, early before being tuberous, regenerated to give multiple (3-4) shoots. This could be because the hypocotyls which later became tuberous begin tuber formation very early in the life of the plant, even before the seedling starts photosynthesizing [40]. The presence of both cotyledons in T. occidentalis could also contribute to the ability of the plant to regenerate early before the roots were noted to have become tuberous [45]. Cotyledon reserves are also known to be important for resprouting during early seedling emergence and establishment [32]. Also, retention of cotyledons in Quercus mongolica seedlings is more important for ensuring seedling resprouting than for supporting seedling growth and survival [44]. After cotyledon degeneration however, shoot regeneration is facilitated by nutrients from tuberous roots. Once seedlings are established, lost tissue is replaced using reserves stored in roots [32].

\section{Conclusion}

In conclusion, it could be established that tuberous roots in Telfairia occidentalis begins to be noticeable eight weeks after planting. The cotyledons which are the energy reserve for seedling begins to degenerate eight weeks after planting, which also coincide with the period the tuberous roots were noticeable. The swollen nexus also has the capacity for shoot regeneration. 
There is a need to investigate the chemical compositions of the roots and cotyledons before and after the root becomes tuberous, to establish the time at which food and energy reserves are being translocated to the roots. So as to have a better understanding of the physiological relationship between the cotyledon and the tuberous roots of $T$. occidentalis.

\section{References}

[1]. J.W. Purseglove, Tropical Crop: Dicotyledon, (Longman Group U.K.Vol.1 1977) (370-373).

[2]. B.E. Okoli and C.M. Mgbeogu, Fluted Pumpkin, Telfairia occidentalis: West African Vegetable Crop. Economic Botany, 37(2), 1983, 145-149.

[3]. P. C.Stevens, Angiosperm Phylogeny Website, version 8, June 2007 [and more or less continuously updated since]. Websitehttp://www.mobot.org/MOBOT/research/APweb/ [accessed 23October 2007].

[4]. H.D. Tindall, Vegetables in the tropics. (Macmillan Press Ltd., London, UK. 1983) 583

[5]. M.O. Akoroda, Ethnobotany of Telfairia occidentalis (Cucurbitaceae) among Igbos of Nigeria. Economic Botany 44(1), 1990a, 2939.

[6]. I.M. Ojeifo, and T.W. Ajekenrenbiaghan,. Evaluation of split seeds of Telfairia occidentalis (Hook F.) for propagation. European Journal of Scientific Research, 14(1), 2006, 21-27.

[7]. E.U Akwaowo, B.A. Ndon, and E.U. Etuk, Minerals and anti-nutrients in fluted pumpkin (Telfaria occidentalis Hook F.). Food Chemistry,70 2000, 235-240.

[8]. R.R. Schippers, African Indigenous Vegetables. An Overview of the Cultivated Species. Chatham, UK: Natural Resources Institute/ACP-EU Technical Center for Agricultural and Rural Cooperation 2000.

[9]. W.B. Akanbi, T.A. Adebayo, O.A Togun, A.S. Adeyeye and O. A. Olaniran, The Use of Compost Extract as Foliar Spray Nutrient Source and Botanical Insecticide in Telfairia occidentalis. World Journal of Agricultural Sciences 3(5), 2007, 642-652.

[10]. S.R. Ajibade, M.O. Balogun, O.O. Afolabi, and M.O. Kupolati, Sex difference in biochemical contents of Telfairia occidentalis Hook F. Journal of Food, Agriculture and Environment 1, 2006, 155-156.

[11]. L.S. Gills, Ethnomedical uses of plants in Nigeria (University of Benin Press, Nigeria. 1992) 276.

[12]. P.I. Akubue, A. Kar and F.N. Nnachetta, Toxicity of extracts of roots and leaves of Telfairia occidentalis. Planta Medica 38, 2008, 339-343

[13]. K.K. Ajibesin, B.A. Ekpo, and D.N. Bala, Antimicrobial activities of the leaves of Combretum micranthum and C. racemosum. Global Journal of Medical Science 1, 2002, 13-17.

[14]. K. Srivastava, K.N. Tiwari, R. Singh, B.D. Singh, and H.K. Jaiwal, Shoot regeneration from immature cotyledons of Cicer arietinum. Biol. Plantarum 44, 2001, 333-337.

[15]. B.B. Lamont, and P.K. Groom, Green cotyledons of two Hakea species control seedling mass and morphology by supplying mineral nutrients rather than organic compounds. New Phytologist. 2002, 153:101-110.

[16]. K. Kitajima, Impact of cotyledon and leaf removal on seedling survival in three tree with contrasting cotyledon functions. Biotropica 35, 2003, 429-434.

[17]. M.E. Hanley, and O.C. May, Cotyledon damage at the seedling stage affects growth and flowering potential in mature plants. New Phytologist. 169, 2006, 243-50.

[18]. Hanley, M.E. and Fegan, E.L., Timing of cotyledon damage affects growth and flowering in mature plants. Plant, Cell and Environment. 30, 2007, 812-819.

[19]. J.R. Stinchcombe, Fitness consequences of cotyledon and mature-leaf damage in the ivy leaf morning glory. Oecologia 131, 2002, 220- 226.

[20]. D. Kabeya, and S. Sakai, The Role of Roots and Cotyledons as Storage Organs in early stage of establishment in Quercus crispula: A Quantitative Analysis of the Nonstructural Carbohydrate in Cotyledons and Roots. Annals of Botany 92, $2003,537-545$.

[21]. J.P. Grime, and D.W. Jeffrey. Seedling establishment in vertical gradients of sunlight. Journal of Ecology. 53, 1965, 621-642.

[22]. D.H. Janzen, Reduction of Mucuna andreana (Leguminosae) seedling fitness by artificial seed damage. Oecologia 94, 1976, 356360.

[23]. P.C. Brookes, D.L. Wigston, and W.F. Bourne, The dependence of Quercus robur and Quercus petrata seedlings on cotyledon potassium, magnesium, calcium and phosphorus during the first year of growth. Forestry 53, 1980, 167-177.

[24]. M. Westoby, E. Jurado, and M.R. Leishman, Comparative evolutionary ecology of seed size. Trends in Ecology and Evolution 7, 1992, 358-372.

[25]. M.R. Leishman, and M. Westoby, The role of large seed size in shaded conditions: experimental evidence. Functional Ecology 8, 1994 205-214.

[26]. K. Kitajima, Cotyledon functional morphology patterns of seed reserve utilization and regeneration niches of tropical tree seedlings. In: Swaine M.D. (Ed.) (New York: Parthenon Publishing Group, 1996), 193-210.

[27]. J.W. Dalling, K.E. Harms, and R. Aizoprua, Seed damage tolerance and seedling resprouting ability of Prioria copaifera in Panama. Journal of Tropical Ecology 13, 1997, 181-490.

[28]. I. Frost, and H. Rydin, Effects of competition, grazing and cotyledon nutrient supply on growth of Quercus robur seedlings. Oikos 79, 1997, 53-58.

[29]. K. Hoshizaki, and S. Suzuki, Impacts of secondary seed dispersal and herbivory on seedling survival in Aesculus turbinata. Journal of Vegetation Science 8, 1997, 735-742.

[30]. C. Bonfil, The effects of seed size, cotyledon reserves, and herbivory on seedling survival and growth in Quercus rugosa and Q. laurina (Fabaceae). American Journal of Botany 85, 1998, 79-87.

[31]. J.W. Dalling, and K.E. Harms, Damage tolerance and cotyledonary resources use in the tropical tree Gustavia superb. Oikos 85, 1999, 257-264.

[32]. M.I. Barberis, and J.W. Dalling, The Effect of Light, Seed Size and Biomass Removal on Cotyledon Reserve Use and Root Mass Allocation in Gustavia superba Seedlings. Journal of Tropical Ecology 24(6), 2008, 607-617.

[33]. M. B. Walters, and P.B. Reich, Low-light Carbon balance and Shade tolerance in the seedlings of woody plants: do winter deciduous and broad-leaved evergreen species differs? New Phytologist 143(1), 1999, 143-154.

[34]. M.B. Walters, and P.B. Reich, Seed size, nitrogen supply, and growth rate affect tree seedling survival in deep shade. Ecology, 81, 2000, 1887-1901.

[35]. M.R. Leishman, I.J. Wright, A.T. Moles, and M. Westoby, The evolutionary ecology of seed size - In: Fenner. M. (ed), Seeds - the ecology of regeneration in plant communities (CAB International 2000) 31-57. 
[36]. P.K. Partel, P.P. Parkeh, and K.D., Sorathia, Studies on Ethnomedicinal aspects of family Cucurbitaceae in North Gujarat. Unique Journal of Pharmaceutical and Biological Sciences 1(1), 2013, 34-36.

[37]. P.R. Shewry, Tuber Storage Proteins. Annals of Botany 91, 2003, 755-769.

[38]. M.O. Akoroda, I.M. Ojeifo, N.I. Odiaka, O.E. Ugwo, and B. Fuwa, Vegetative Structure of the Perennating Organ of Telfairia occidentalis. European Journal of Scientific Research 14(1), 2006, 6-20.

[39]. M. Akoroda, "Status of tuber crop production and utilization in Africa" A paper presented at The $14^{\text {th }}$ Triennial Symposium of the International Society for Tropical Root Crops (ISTRC). 27 November, 2006, No.1878

[40]. R.A. Schlising, Seedling Morphology in Marah (Cucurbitaceae) Related to the California Mediterranean Climate. American Journal of Botany 56(5), 1969, 552-561.

[41]. S.S.C. Onyekwelu, Germination, seedling morphology and establishment of Combretum bauchiense Hutch and Dalz. (Combretaceae). Botanical Journal of the Linnean Society 103(2), 1990, 133-138.

[42]. J. Tsuno, and K. Fujise, Studies on the dry matter production of the sweet potato. VIII. The internal factors' influence on photosynthetic activity of the sweet potato leaf. Proc. Crop Sci. Soc. Japan 33, 1964d, 230-235.

[43]. S.K. Halms, and Y. Hozyo, Sweet Potato and Yam. Symposium on Potential Productivity of Field Crops under different Environment, 1983, 319-340.

[44]. X.F. Yi, and C.Q. Liu, Retention of cotyledons is crucial for resprouting of clipped oak seedlings. Scientific Report 4, $2014,5145$.

[45]. D. N. Iortsuun, A. M. Chia, and A. F. Adeola, The effect of seed mass and cotyledon removal on the germination and growth of fluted pumpkin. (Telfaria occidentalis Hook. F). Science World Journal 3, 2008, 25-31.

[46]. P.M. Forget, Seed removal and seed fate in Gustavia superba (Lecythidaceae). Biotropica 24, 1992, $408-414$.

[47]. M.O. Fawole, M.O. Olofinboba, and E.O. Etejere, Seed germination in Eupatorium odoratum: Changes in food reserves and oxygen uptake. Nigeria Journal of Science 13, 1979, 286-293. 